\title{
Processing of Olein Fraction Red Palm Oil with Minimal Refining Method and Optimization of Deodorization Process
}

\author{
Deny Sumarna ${ }^{1, *}$, Sumardi Hadi Sumarlan ${ }^{2}$, Susinggih Wijaya ${ }^{2}$, and Nur Hidayat ${ }^{2}$ \\ ${ }^{1}$ Department of Agricultural Product Technology, Faculty of Agriculture, Mulawarman University, Jl. Paser \\ Balengkong Kampus Gunung Kelua, Samarinda, 75119, Indonesia \\ ${ }^{2}$ Department of Agricultural Industry Technology, Faculty of Agricultural Technology, Brawijaya University, Malang, \\ Indonesia \\ "Corresponding author. Email : dsumarna@faperta.unmul.ac.id
}

\begin{abstract}
Red Palm Olein (RPOn) is the result of refining and fraction of Crude Palm Oil (CPO). In the conventional refining of $\mathrm{CPO}$, carotene which is a pro-Vitamin A is intentionally removed to get a clear colored oil.. This research is comparing between two methods are Method I and Method II. Method I is started from degumming process (acid degumming), Neutralization, deodorization, and then fractionation. Meanwhile, Method II is started from degumming process (water degumming), fractionation and then deodorization. Optimization using RSM method with CCD program, carried out in the deodorization process of the selected by method II. Method II is producing RPOn with $0.1949 \%$ moisture content, $0.8743 \mathrm{mE} / \mathrm{kg}$ peroxide value, $0.148 \%$ FFA, $57.5380 \mathrm{ppm}$ of beta carotene and $100.5526 \mathrm{ppm}$ of tocopherol alpha. Improvement of the deodorization process using RSM by setting the temperature to $90^{\circ} \mathrm{C}$, vacuum pressure to $50 \mathrm{cmHg}$ and 2.98 hours of deodorization process will be produce RPOn with $0.03 \%$ FFA.
\end{abstract}

Keywords: Red Palm Olein, Response Surface Method, Degumming, Beta Caroten, FFA.

\section{INTRODUCTION}

Crude palm oil (CPO) comes from the fruit of the palm oil (Elaeis guineensis), a tropical plant species native to West Africa. CPO is extracted from the palm mesocarp with a mechanical screw-press extraction process [1], [2]. In refining palm oil process, part of carotene is removed through bleaching process that followed with deodorization in high temperature that can spoil the carotene for getting clear palm oil [3]. CPO with rich beta carotene is important in the deficiency context of Vitamin A. Red Palm Oil (RPO) is the result of refining from CPO that produce high carotene content, is signed with red oil product. In the final product, RPO have a lot of varian product based on fractionation process. There are 5 variant of RPO: Red Palm Oil, Red Palm Olein, Red Palm Stearin, Red Palm Super Olein, and Red Palm mid-fraction [4].

RPO application research has been done for food product, healt, and skin care lotion [4]-[10]. The effort for maintaining nutrition value in CPO process ever did it using supercritical carbondioxide method, molecular destillation, and membrane technology [11]-[14]. In this time, the refining of CPO especially in cooking oil manufacturing process (RBDPO) has damaged carotenoid pigments in bleaching process [15]. Several stages of the CPO purification process, namely degumming, neutralization, and deodorization can reduce the carotene content

Correction in refining palm oil steps, especially removing bleaching's step will produce palm oil with high carotenoids, known as Red Palm Oil (RPO). Degumming process is the first process (pretreatment) in refining process for removing Gum. Gum is general term for minor content in CPO that complex compounding of phospholipid, glycolipid, sugar, protein, and other water soluble compound in CPO [16], [17]. Phospholipid reduction's oil in bleaching process will be absorbed on the bleaching clay which will reduce its effectiveness in the ability to remove chlorophyll and its derivatives [18][21]. The phospholipid can cause decolorization oil, has function as the main precursor off flavor and causes loss of neutral lipids during neutralization in the refining general process [22] . Moreover, Phospholipid or gum is 
considered as undesirable substance because can make dirty equipment pipe in high temperature process [23].

The degummng process that is usually done in palm oil processing is by using acid. It is degumming process whose process uses phosphotic acid $\left(\mathrm{H}_{3} \mathrm{PO}_{4}\right)$ dan warm water. Giving phosphotic acid and water $\left(60{ }^{\circ} \mathrm{C}\right)$ is intended for removing non-hydratable phospatides. Phosphotic acid can change it to hydratable shape. Hydratable phospatides like phosphatidycholine (lesitin), can easily remove from oil using water [24], [16], [20]. Besides of degumming process, neutralization using $\mathrm{NaOH}$ and high temperature deodorization can damage the carotene [25], [26].

By modifying the method, processing or controlling the temperature factor, the length process of conventional refining process is expected to maintain minor components (carotene and tocopherol) and still maintain oil quality based on FFA parameters, moisture content and PV. With consideration potential nutrition value, then refining research and fractionation in CPO being Red Palm Olein (RPOn) with minimal processing method which is a modification of the conventional refining process. It started from degumming process, neutralization, deodorization, and fractionation. Comparison of the two selected refining process are followed by optimization of the deodorization using controlling the temperature, vacuum pressure and process time.

\section{METHODS}

This research uses CPO from PT Wilmar Nabati Indonesia. The process of refining palm oil into RPOn uses two processing methods. In method I is started from degumming process (acid degumming), neutralization, deodoritation, and then fractionation. Meanwhile, method II is started from degumming process (water degumming), fractionation and then deodorization. Each method using different arrangement process except degumming process. In method I degumming process using acid degumming and method II using water degumming. Method I and method II using different arrangement refining process. Another difference is only method I using neutralization process with $\mathrm{NaOH}$.

Water degumming is a treatment on CPO using water $\left(60{ }^{\circ} \mathrm{C}\right)$. Acid degumming as like as water degumming process but there are addition of phosphoric acid $\left(\mathrm{H}_{3} \mathrm{PO}_{4}\right)$. Neutralization using $\mathrm{NaOH}$ with excess $0.10 \%$ of oil weight. Fractionation using dry fractionation method is saving oil in room temperature within 24 hours, Deodorization process carried out in $80{ }^{\circ} \mathrm{C}$ temperature with 80 mbar vacuum pressure within an hour[27].

From RPOn that produce from the best selected method, the next step is to optimize the deodorization process. This optimize is using Response Surface Methodology (RSM) with Central Composite Design (CCD). Alpha value is calculated based on the formula $\alpha$
$=2 \mathrm{k} / 4, \mathrm{k}$ is the number of variable tested. This experiment is used three independent variables: temperature $(\mathrm{A})$, pressure $(\mathrm{B})$, time $(\mathrm{C})$. Observe the responses is FFA percentage. . In addition, then 20 runs included 8 factorial points, 6 axial points, and 6 replicates at the center point to determine the experimental error for this study.

Experimental data is obtained will be analyzed using a second-order polynomial to find the connection between independent variable with FFA.

$$
Y=\beta_{0}+\sum_{i=1}^{k} \beta_{i} X_{i}+\sum_{i=1}^{k} \beta_{i i} X_{i}^{2}+\sum \sum_{i<j} \beta_{i j} X_{i} X_{j}+\varepsilon
$$

$\mathrm{Y}$ is response (FFA), $\beta$ o is intercept $\beta \mathrm{i}, \beta \mathrm{ii}, \beta \mathrm{i}, \mathrm{j}$ are linear, quadratic, and interactive coefficient, respectively, $\mathrm{k}$ is the number of factor, and $\mathrm{Xi}$ and $\mathrm{Xj}$ are independent variables under study.

Table 1. The center composite program of deodorization process with three independent variable.

\begin{tabular}{|c|l|l|l|l|l|}
\hline Code & \multicolumn{1}{|c|}{ Name } & $\begin{array}{c}\text { Low } \\
\text { code }\end{array}$ & $\begin{array}{l}\text { High } \\
\text { code }\end{array}$ & Low & High \\
\hline A & $\begin{array}{l}\text { Deodorization } \\
\text { temperatur } \\
\text { (0C) }\end{array}$ & -1 & 1 & 90 & 150 \\
\hline B & $\begin{array}{l}\text { Vacuum } \\
\text { pressure } \\
\text { (cmHg) }\end{array}$ & -1 & 1 & 50 & 60 \\
\hline C & Time (hour) & -1 & 1 & 1 & 3 \\
\hline
\end{tabular}

\subsection{Determination of FFA, Peroxide value and Moisture content}

The FFA of oil sample were determined using AOCS Official recommended method $\mathrm{Ca}$ 5a-40. Moisture content (AOCS Official Method Ca 2c-25 2012). Peroxide value (SNI 3741:2013)

\subsection{Determination of alpha tocopherol}

Oil sample were dissolved in etanol; the absorbance was measured at $446 \mathrm{~nm}$. The carotenoid content of oil samples was expressed as $\mathrm{mg}$ alpha-tokoferol $/ \mathrm{kg}$ oil (ppm)

\subsection{Determination of beta-carotenoids}

Carotenoids were determined according to PORIM test method (PORIM, 1995). Oil Sample were dissolved in hexane; the absorbance was measured at $291 \mathrm{~nm}$. The carotenoid content of oil samples was expressed as $\mathrm{mg}$ beta-carotene $/ \mathrm{kg}$ oil (ppm) 


\subsection{Statistical Analysis}

The statistical analysis was perfomed using Microsoft Excel. Analysis of variance (ANOVA) was used to the oil quality parameters at significance level $(\alpha)$ of 0.05 . Further significance difference was tested by Tukey's test.. Process optimization using Response Surface Method (RSM) with Central Composite Design (CCD) and using Design Expert 6.0.8 software.

\section{RESULTS AND DISCUSSION}

\subsection{Method I vs Method II}

Table 2. Influence of CPO Processing Toward Moisture Content, Peroxide Value, FFA, Beta-Carotene, Alpha Tecoferol in RPOn Processing

\begin{tabular}{|c|c|c|c|c|c|}
\hline & $\begin{array}{c}\text { Moisture } \\
\text { content (\%) }\end{array}$ & $\begin{array}{c}\text { Peroxide } \\
\text { value } \\
\text { (mE/kg) }\end{array}$ & FFA (\%) & $\begin{array}{l}\text { Beta carotene } \\
\text { (ppm) }\end{array}$ & $\begin{array}{l}\text { AlfaTokoferol } \\
\text { (ppm) }\end{array}$ \\
\hline Crude Palm Oil (CPO); & $\begin{array}{l}0.2385 \\
\pm 0.0504\end{array}$ & $\begin{array}{l}2.3086 \\
\pm 0.1105\end{array}$ & $\begin{array}{l}1.1376^{a} \\
\pm 0.0881\end{array}$ & $\begin{array}{l}53.5940 \text { abc } \\
\pm 1.1928\end{array}$ & $\begin{array}{l}108.5526 \\
\pm 0.9977\end{array}$ \\
\hline \multicolumn{6}{|l|}{ Method I } \\
\hline Acid Degumming (GPO); & $\begin{array}{l}0.2266 \\
\pm 0.0216\end{array}$ & $\begin{array}{l}1.9473 b \\
\pm 0.0910\end{array}$ & $\begin{array}{l}0.6126 \text { b } \\
\pm 0.0214\end{array}$ & $\begin{array}{l}52.1020 \text { bc } \\
\pm 1.2739\end{array}$ & $\begin{array}{l}99.5264 d \\
\pm 0.8746\end{array}$ \\
\hline Neutralized Palm Oil (NPO); & $\begin{array}{l}0.2314 \\
\pm 0.0344\end{array}$ & $\begin{array}{l}1.6313 c \\
\pm 0.0015\end{array}$ & $\begin{array}{l}0.0562 \text { de } \\
\pm 0.0289\end{array}$ & $\begin{array}{l}50.1840 c \\
\pm 3.2602\end{array}$ & $\begin{array}{l}91.4738 \text { e } \\
\pm 1.5528\end{array}$ \\
\hline $\begin{array}{l}\text { Neutralized Deodorized Palm Oil } \\
\text { (NDPO); }\end{array}$ & $\begin{array}{l}0.1955 \\
\pm 0.0644\end{array}$ & $\begin{array}{l}1.1919 d \\
\pm 0.1068\end{array}$ & $\begin{array}{l}0.0715 \text { de } \\
\pm 0.0388\end{array}$ & $\begin{array}{l}51.3900 \text { bc } \\
\pm 2.9906\end{array}$ & $\begin{array}{l}93.3946 \text { e } \\
\pm 1.0713\end{array}$ \\
\hline $\begin{array}{l}\text { Neutralized Deodorized Palm Olein } \\
\text { (RPOn); }\end{array}$ & $\begin{array}{l}0.1998 \\
\pm 0.0142 \\
\end{array}$ & $\begin{array}{l}0.8742 \text { e } \\
\pm 0.0882 \\
\end{array}$ & $\begin{array}{l}0.0459 \text { e } \\
\pm 0.0491 \\
\end{array}$ & $\begin{array}{l}53.4820 \mathrm{abc} \\
\pm 4.6142\end{array}$ & $\begin{array}{l}102.9210 \text { bc } \\
\pm 1.2600\end{array}$ \\
\hline \multicolumn{6}{|l|}{ Method II } \\
\hline Water Degumming (GPO); & $\begin{array}{l}0.2202 \\
\pm 0.0305 \\
\end{array}$ & $\begin{array}{l}1.9066 \text { b } \\
\pm 0.0899 \\
\end{array}$ & $\begin{array}{l}0.6984 b \\
\pm 0.0362 \\
\end{array}$ & $\begin{array}{l}53.2120 \text { abc } \\
\pm 2.8787 \\
\end{array}$ & $\begin{array}{l}100.5526 \mathrm{~cd} \\
\pm 1.3398\end{array}$ \\
\hline Degummed Palm Olein (GPOn); & $\begin{array}{l}0.2131 \\
\pm 0.0199\end{array}$ & $\begin{array}{l}0.8354 \text { e } \\
\pm 0.1078\end{array}$ & $\begin{array}{l}0.2396 c \\
\pm 0.0379\end{array}$ & $\begin{array}{l}55.9240 \text { ab } \\
\pm 1.2595\end{array}$ & $\begin{array}{l}104.9474 b \\
\pm 1.3693\end{array}$ \\
\hline Deodorized Palm Olein (RPOn); & $\begin{array}{l}0.1949 \\
\pm 0.0191\end{array}$ & $\begin{array}{l}0.8743 \text { e } \\
\pm 0.1119\end{array}$ & $\begin{array}{l}0.1480 \mathrm{~cd} \\
\pm 0.0214\end{array}$ & $\begin{array}{l}57.5380 \text { a } \\
\pm 0.0371\end{array}$ & $\begin{array}{l}100.8686 \mathrm{~cd} \\
\pm 0.6059\end{array}$ \\
\hline
\end{tabular}

RPOn process is using method I and method II. In every process is indicating the differences (Table 2) except moisture content parameter. There is a decrease in the number of peroxides (62.13\%) and FFA (95.97), after acid degumming, neutralization, deodorization, fractionation process (method I), meanwhile in method II after water degumming process, fractionation, and deodorization process, peroxides value $(62.12 \%)$ and FFA (86.99\%). This significant decrease of FFA because in method I, neutralization process is using $\mathrm{NaOH}$ to remove FFA through the saponification process, whereas in method II, the decrease because of washing process with warm water and sufficient heating treatment to remove excess water in water degumming, and then deodorization process in $80^{\circ} \mathrm{C}$ temperature with $80 \mathrm{mbar}$ vacuum pressure within an hour, FFA is distilled in the vapor phase that causes FFA's decrease in RPOn process [28].

The concentration of Beta Carotene in method I and method II in the end of process are not indicating the significant differences, but during the neutralization process it shows the decrease and tends to increase after fractionation process. The concentration of alpha tocopherol is showing decrease in method I $(5.19 \%)$ although in method II (7.08\%). 
of this research showed that acid degumming method, which phosphate acid in $60{ }^{\circ} \mathrm{C}$ decreased beta-carotene from $53.59 \mathrm{ppm}$ to $52.10 \mathrm{ppm}(3 \%)$, while in water degumming method decreased from $53.59 \mathrm{ppm}$ to 53.21 ppm (1\%), the decreases didn't seem any different. The decreased also happened in alpha tocopherol from 108.55 ppm to $99.53 \mathrm{ppm}(8 \%)$ in acid degumming method; while in water degumming method from $108.55 \mathrm{ppm}$ to $100.55 \mathrm{ppm}$ (7\%), the differences was clear. The decreases of beta-carotene and tocopherol was accordance with research by You et al [18], it showed that using phosphate acid 0.49 into 200 gram CPO in $60{ }^{\circ} \mathrm{C}$ would decrease beta-carotene from $680.67 \mathrm{ppm}$ into $625.00 \mathrm{ppm}$, in other word there are $55.67 \mathrm{ppm}$ decreases (8\%), and also in a research by Nur Sulihatimarsylia et al., [25] there were decreasing in carotenoid and tocopherol after acid degumming and water degumming process. The decreasing of beta-carotene and alpha tocopherol is not only due to phosphate acid but also the water that was used in degumming process. Degumming process threw away not only water but also oil that contained betacarotene [25], [26], [29].

Content of FFA in CPO that has been degummed with water decreased along with gum's elevation. Phospholipid removal in CPO (using degumming) caused decreasing FFA in oil, from $1.13 \%$ to $0.61 \%$ $(0.52 \%)$ in acid degumming and from $1.13 \%$ to $0.70 \%$ $(0.43 \%)$ in water degumming. FFA decreasing was detected in drying process which losing over water that used in degumming before another step. A good handle of degumming process that restrained/decreased hydrophilic process was conditioned time zone the water contacted with oil and also the separation. The similar result showed in Nur Sulihatimarsyila et al [25], where FFA in PPFO decreased from $5.30 \%$ to $5.11 \%$ in water degumming process.

Degumming method as a pretreatment from this research-result showed that using water degumming and acid degumming seemed no differences according the observation parameter (FFA, moisture content, betacarotene, alpha-tocopherol, peroxide value). However the process was different, water degumming didn't use chemical (phosphate acid), so it was more natural. The use of water in water degumming process was lesser than acid degumming process. In acid degumming, washing process would continuously do until $\mathrm{pH}$ back to normal. Usage of water and water separation with sedimentation method would take more time because washing process was done repeatedly. Beside that losing neutral oil in acid degumming process $(2.75 \%)$ was more than water degumming (1.87\%).

\subsection{Neutralization}

According to the result of research, average of FFA palm oil after neutralization was decreased to $0.06 \%$ from FFA degree $1.14 \%$, along with the average of rudiment oil decreased $5.7 \%$ from rudiment before (degummed palm oil). This was showed that added $\mathrm{NaOH}$ in degummed palm oil gave a significant result in decreasing FFA in oil through soap process. It can be happened in several neutral oil, so that neutral oil can be thrown [30]. Compared with research conducted by Mayamol et al. [27], influence of neutralization on reduction of FFA showed that a tenfold reduction in the percentage of FFA had occurred for NPO and increasing the neutral oil loss. Widarta, Nuri and Haryati [31] reported that neutralization stage of NRPO (Neutralized Red Palm Oil) for pilot plant scale could reduce FFA to $0.13 \%$.

The average of moisture content palm oil after neutralization didn't show any differences, in $0.20 \%$. the highest of moisture content was depend on separation process and $\mathrm{NaOH}$ concentration using low soluble alkali $\mathrm{NaOH}$ caused emulsion between oil and soap. That emulsion trapped the water from soluble alkali $\mathrm{NaOH}$ and the sample, so it spread into emulsion and can't be separated. In concentration of higher soluble alkali $\mathrm{NaOH}$, the emulsion didn't happen, the soluble alkali $\mathrm{NaOH}$ along with free fat acid shaped soap degree from neutralization was lower. Neutralization process used so many water, especially washing remains $\mathrm{NaOH}$. The oil was washed in water so that remains $\mathrm{NaOH}$ and soap would be thrown perfectly, it was marked by $\mathrm{pH}$ that nearly 7 (neutral). The amount of water and time in water-oil separation was the weakness of neutralization process, where the volume of water and oil were 1:1 [27], [30].

\subsection{Last Product Red Palm Olein (RPOn)}

The result of research showed that using method I and II, the quality of RPOn was not seem any differences in physic and chemical observation (moisture content, FFA, $\mathrm{PV})$, but there are clear differences in some component observation on first source, CPO. Oil inclined to react with oxygen auto-oxidation, it was not only incline with fat oil composition but also another component in it, such as natural pro-oxidant and anti-oxidant like carotenoid and tocopherol, or some certain heavy metal like copper and iron that can be worked as pro-oxidant. Thus, low number of pre-oxidant in RPOn can be connected with some carotenoid in high concentration and also tocopherol that function as anti-oxidant, so that fat oxidation process can be prevented. Beta-carotene could stabilize radical component from oil with hydrogen donor to lipid radical and radical peroxyl [32]. In carotenoid observation ( $\beta$-carotene) and alpha tocopherol, RPO that had no enhanced in concentration, it was similar with CPO (Table 2). Through deasidification process with $\mathrm{NaOH}$ or through deodorization process in $80{ }^{\circ} \mathrm{C}$ and vacuum 80 mbar, beta-carotene still survived. 
Table 3. Quality of Crude Characteristic and Red Palm Oil Compare with Another Research

\begin{tabular}{|c|c|c|c|c|}
\hline Sampel & FFA (\%) & $\mathrm{PV}(\mathrm{mE} / \mathrm{kg})$ & $\beta$-karoten (ppm) & $\begin{array}{c}\text { Tokoferol alpha } \\
\text { (ppm) }\end{array}$ \\
\hline $\mathrm{CPO}^{\mathrm{a}}$ & 3.53 & 2.32 & 56.00 & 187.00 \\
\hline $\mathrm{CPO}$ & 1.14 & 2.31 & 53.59 & 108.55 \\
\hline Red Palm Olein ${ }^{\mathrm{a}}$ & 0.04 & 0.10 & 33.30 & 166.00 \\
\hline Red Palm Oil & 1.27 & & & \\
\hline Red Palm Oilc & 0.49 & 0.12 & & \\
\hline Refined Palm Oild & 0.14 & 1.08 & & \\
\hline Red Palm Olein (Metode I) & 0.05 & 0.87 & 53.48 & 102.92 \\
\hline Red Palm Olein (Metode II) & 0.15 & 0.87 & 57.54 & 100.87 \\
\hline
\end{tabular}

${ }^{\mathrm{a}}[4] ;{ }^{\mathrm{b}}[33] ;{ }^{\mathrm{c}}[34] ;{ }^{\mathrm{d}}[30]$;

From Table 3, showed that quality of RPOn in this research was similar with other research, FFA's score war near $<0.1 \%$, meanwhile PV was still between 0.1 . to $0.08 \mathrm{mE} / \mathrm{kg}$. While $\beta$-carotene concentration in method I and II could maintain its concentration (not significant) and a little decline in alpha tocopherol concentration $(5.19 \%$ and $7.08 \%)$. Comparing parameter quality with other research showed that method I and II could be used to produce high quality RPOn. Between method I and II, method I had advantage in FFA's low percentage. This was because in its process $\mathrm{NaOH}$ used as chemical material and it worked effectively to lower FFA. In method II, FFA can be lower by repairing deodorization

Table 4. Experimental Design with Observed and Predicted Values

\begin{tabular}{|c|c|c|c|c|c|}
\hline \multirow{2}{*}{ No } & \multicolumn{3}{|c|}{ Coded } & \multirow{2}{*}{$\begin{array}{c}\text { Observed } \\
\text { FFA }\end{array}$} & \multirow{2}{*}{$\begin{array}{c}\text { Predicted } \\
\text { FFA } \\
\end{array}$} \\
\hline & A-Temperature & B-Pressure & C-Time & & \\
\hline 1 & -1 & 1 & -1 & 0.153 & 0.241 \\
\hline 2 & -1 & -1 & -1 & 0.153 & 0.222 \\
\hline 3 & 1 & 1 & 1 & 0.179 & 0.199 \\
\hline 4 & 0 & 0 & 1.682 & 0.025 & 0.051 \\
\hline 5 & 0 & -1.682 & 0 & 0.230 & 0.189 \\
\hline 6 & 0 & 0 & 0 & 0.460 & 0.484 \\
\hline 7 & 1.682 & 0 & 0 & 0.281 & 0.028 \\
\hline 8 & 1 & -1 & -1 & 0.051 & 0.128 \\
\hline 9 & -1 & 1 & 1 & 0.025 & 0.038 \\
\hline 10 & 0 & 0 & 0 & 0.486 & 0.484 \\
\hline 11 & 0 & 0 & 0 & 0.508 & 0.484 \\
\hline 12 & 1 & 1 & -1 & 0.051 & 0.147 \\
\hline 13 & 0 & 1.682 & 0 & 0.306 & 0.221 \\
\hline 14 & -1.682 & 0 & 0 & 0.204 & 0.151 \\
\hline 15 & 1 & -1 & 1 & 0.178 & 0.180 \\
\hline 16 & 0 & 0 & -1.682 & 0.330 & 0.178 \\
\hline 17 & 0 & 0 & 0 & 0.535 & 0.484 \\
\hline 18 & -1 & -1 & 1 & 0.026 & 0.019 \\
\hline 19 & 0 & 0 & 0 & 0.383 & 0.484 \\
\hline 20 & 0 & 0 & 0 & 0.510 & 0.484 \\
\hline
\end{tabular}


process in controlling temperature, pressure and time a process take to get optimum solution in using RSM.

\subsection{Optimize Deodorization in RPOn Process}

Optimize process in this research was done in deodorization process from method II with 3 variables independent such as temperature, pressure and time using responses of FFA percentage. The target of deodorization was volatile compound [35], so that it was done in high temperature of processing RBDPO [21]. Because this research was making RPO so the temperature had to be as low as possible, it was for decreasing FFA[29], [34] .

RSM was employed to evaluate the relation between the responses (FFA) and the 3 reaction variables. The result in every point based on CCD experimental plans is shown in Table 4 . The responses from regression analysis are correlated with 4 variables independent using polimial equation orde 2 . The scores that are observed are variation such as $0.025 \%$ in temperature $90^{\circ} \mathrm{C}$ pressure $60 \mathrm{cmHg}$, and time 3 hours, or $0.5353 \%$ in temperature $120 \mathrm{oC}$, pressure $-55 \mathrm{cmHg}$ and time 2 hours.

Table 5. Summary of regression coeficients, P-values, and fitting parameter model responses

\begin{tabular}{|c|c|c|}
\hline Response model & FFA (\%) & \\
\hline Sugested model & Quadratic & \\
\hline Model P-value & $0.0029 *$ & \\
\hline R2 & 0.8612 & \\
\hline Adj. R2 & 0.7362 & \\
\hline Pred. R2 & 0.0973 & \\
\hline Adeq.Prec & 7.172 & \\
\hline Lack of Fit & 0.0562 & \\
\hline Parameters & $\mathrm{RC}$ & $\mathrm{p}$-value \\
\hline Intercept & 0.4806 & \\
\hline A & 0.0169 & 0.5102 \\
\hline B & 0.0094 & 0.7115 \\
\hline C & -0.03765 & 0.1601 \\
\hline$A 2$ & -0.1078 & 0.0012 \\
\hline B2 & -0.1078 & 0.0022 \\
\hline $\mathrm{C} 2$ & -0.1307 & 0.0003 \\
\hline$A B$ & $9.55 \mathrm{E}-05$ & 0.9977 \\
\hline$A C$ & 0.0638 & 0.0775 \\
\hline$B C$ & $2.72 \mathrm{E}-05$ & 0.9993 \\
\hline
\end{tabular}

A: Temperature $\left({ }^{\circ} \mathrm{C}\right)$; B: Vacuum Presure $(\mathrm{cmHg})$; C: Time (hour); $\mathrm{RC}$ : regression coefficient; $\mathrm{R}^{2}$ : determination coefficient; Adj. $\mathrm{R}^{2}$ : adjusted $\mathrm{R}^{2} ; \mathrm{R}^{2}$ :predicted $\mathrm{R}^{2}$; Adeq.Prec : Adequate precicision; $* \mathrm{P}<$ 0.05

Statistic test result using Design Expert, anova are used to know the effect from variable to $\mathrm{Y}$ responses, showed that the model had a real impact or significant to responses where $\mathrm{p}$-value $=0.003$ or smaller than 0.05
[36]. The p-value of the lack of fit was 0.0562 , indicating that it was not significant. Therefore, the number of experiments was sufficient to determine the effect of the variables on FFA. Model suitability is tested too using equation of regression and coefficient determination (R2). The high value of R2 (0.8612) indicates that the fitted model can be used to predict reasonably precise outcomes.

From Table 5, factor of pressure $\left(\mathrm{A}^{2}\right)$, temperature $\left(B^{2}\right)$ and time $\left(C^{2}\right)$ were found to be significant at the $95 \%$ confidence level according to computed F-value (high) and p-value at $5 \%$ level. The statistical tests indicate that the selected model is satisfactory for predicting the FFA within the scope of the studied variables, and also shows that the quadratic model is valid in the present study. The smaller the $\mathrm{p}$-value for parameter, more significant the parameter is.

\subsection{Optimization Responses FFA}

Criteria or objective function that is used to set the optimum conditions which are suitable with the limitations (constraints) as in Table 6. Goal constraints that are given with minimum temperature, pressure and time would lower the damage risk at minor content that had nutrition and also decreased resources. Given constraints are expected to give minimum FFA percentage.

Table 6. Constraints Responses for Optimum

\begin{tabular}{|c|c|c|c|}
\hline Name & Goal & $\begin{array}{l}\text { Lower } \\
\text { Limit }\end{array}$ & $\begin{array}{l}\text { Upper } \\
\text { Limit }\end{array}$ \\
\hline A:Temperature (OC) & minimize & 90 & 150 \\
\hline $\begin{array}{l}\text { B: Vacuum Pressure } \\
(\mathrm{cmHg})\end{array}$ & minimize & 50 & 60 \\
\hline C: Time(hour) & is in range & 1 & 3 \\
\hline FFA (\%) & minimize & 0.0253 & 0.5353 \\
\hline
\end{tabular}

From the constraints criteria in Table 6, software Design Expert offered 8 optimum solutions, in first row highest desirability score was 0.9999 that temperature treatment, pressure and temperature would give optimum FFA (Table 7).

According to result in Table 7, there were 8 optimum solutions chosen by FFA lowest and highest desirability score. FFA responses that are offered by RSM model was in temperature $90{ }^{\circ} \mathrm{C}$, pressure $-50 \mathrm{cmHg}$ and time 2.98 hours. That solution result would show FFA quality in $0.03 \%$. Desirability result on the exact optimal solution showed 0.99 . Desirability score 1 indicated response the perfect case, but desirability 0 indicated response the thrown case [37].

From result of optimum solution chosen, was done in validation test (Table 8) 3 times test with hour that compromised into 3 hours, is gained FFA score with differences 0.02 to 0.05 higher than predicted score, but 
Table 7. Optimal Solution

\begin{tabular}{|c|c|c|c|c|c|c|}
\hline No. & $\begin{array}{c}\text { Temperature } \\
\left({ }^{\circ} \mathrm{C}\right)\end{array}$ & $\begin{array}{c}\text { Pressure } \\
(\mathrm{cmHg})\end{array}$ & $\begin{array}{c}\text { Time } \\
(\text { Hour })\end{array}$ & $\begin{array}{c}\text { FFA } \\
(\%)\end{array}$ & Desirability \\
\hline 1 & 90.00 & 50.00 & 2.98 & 0.03 & 0.999999 & Selected \\
\hline 2 & 90.00 & 50.51 & 3.00 & 0.04 & 0.973472 & \\
\hline 3 & 90.00 & 50.00 & 2.86 & 0.07 & 0.971939 & \\
\hline 4 & 93.51 & 50.00 & 3.00 & 0.05 & 0.962533 & \\
\hline 5 & 90.00 & 50.00 & 1.00 & 0.22 & 0.849369 & \\
\hline 6 & 90.00 & 50.00 & 1.09 & 0.24 & 0.837624 & \\
\hline 7 & 90.00 & 50.00 & 1.88 & 0.26 & 0.812908 & \\
\hline 8 & 116.68 & 50.00 & 1.00 & 0.29 & 0.646898 & \\
\hline
\end{tabular}

observed score that can be expected. From the results of the chosen optimum solution, a validation test (Table 8) was carried out 3 times with a compromised time of 3 hours, the FFA score was obtained with a difference of 0.02 to 0.05 higher than the predicted score. This shows that using a temperature of $90{ }^{\circ} \mathrm{C}$, a vacuum pressure of $50 \mathrm{cmHg}$ for 3 hours gives results that are not different from the RSM model

\section{CONCLUSION}

Purifying method, minimum CPO to RPOn is started with water degumming, fractionation then deodorization process (method II) has given parameter quality (moisture content and PV) that were not significant with purifying process that involved chemical (method I) in its process, beta-carotene and alpha tocopherol too. Decreased FFA content in method II can be optimazed by controlling parameter in temperature, vacuum pressure and time of deodorization. Using RSM process in temperature $90{ }^{\circ} \mathrm{C}$, pressure $-50 \mathrm{cmHg}$ and time 2.98 hours would get RPOn with FFA score in $0.03 \%$.

\section{REFERENCES}

[1] O. A. Adetola, J. O. Olajide, and A. P. Olalusi, Development of a Screw Press for Palm Oil Extraction, Int. J. Sci. Eng. Res., vol. 5, no. 7, 2014.

[2] M. H. Ng and Y. M. Choo, Improved Method for the Qualitative Analyses of Palm Oil Carotenes Using UPLC, J. Chromatogr. Sci., vol. 54, no. 4, 2016, DOI: 10.1093/chromsci/bmv241.

[3] Y. L. Kua, S. Gan, A. Morris, and H. K. Ng, Optimization of simultaneous carotenes and vitamin E (tocols) extraction from crude palm olein using response surface methodology, Chem. Eng. Commun., 2018, DOI: 10.1080/00986445.2017.1407760.

[4] B. Nagendran, U. R. Unnithan, Y. M. Choo, and K. Sundram, Characteristics of red palm oil, a carotene- and vitamin E-rich refined oil for food uses, Food Nutr. Bull., 2000, DOI: $10.1177 / 156482650002100213$.
N. N. M. M. El-Hadad, M. M. Youssef, M. H. Abd El-Aal, H. H. Abou-Gharbia, and M. H. A. El-Aal, Utilisation of red palm olein in formulating functional chocolate spread, Food Chem., vol. 124, no. 1, 2011, DOI: 10.1016/j.foodchem.2010.06.034.

[6] S. Dong, H. Xia, F. Wang, and G. Sun, The effect of red palm oil on vitamin a deficiency: A metaanalysis of Randomized controlled trials, Nutrients, vol. 9, no. 12, 2017, DOI: 10.3390/nu9121281.

[7] N. Ermatov, S. Guli, S. Feruza, A. Feruza, and R. Bakhtiyor, The effectiveness of red palm oil in patients with gastrointestinal diseases, Int. J. Pharm. Res., 2019, DOI: 10.31838/ijpr/2019.11.04.065.

[8] C. Zhu, Y. Cai, E. R. Gertz, M. R. La Frano, D. J. Burnett, and B. J. Burri, Red palm oilsupplemented and biofortified cassava gari increase the carotenoid and retinyl palmitate concentrations of triacylglycerol-rich plasma in women, Nutr. Res., vol. 35, no. 11, 2015, DOI: 10.1016/j.nutres.2015.08.003.

[9] R. Loganathan, K. M. Subramaniam, A. K. Radhakrishnan, Y. M. Choo, and K. T. Teng, Health-promoting effects of red palm oil: Evidence from animal and human studies, Nutr. Rev., 2017, DOI: 10.1093/nutrit/nuw054.

[10] M. Chaijan and W. Panpipat, Pre-neutralized crude palm oil as natural colorant and bioactive ingredient in fish sausage prepared from tilapia (Oreochromis niloticus), Lwt, vol. 135, 2021, DOI: 10.1016/j.lwt.2020.110289.

[11] D. Liu, J. Shi, L. R. Posada, Y. Kakuda, and S. J. Xue, Separating tocotrienols from palm oil by molecular distillation, Food Rev. Int., 2008, DOI: 10.1080/87559120802303840.

[12] Iftikhar, H. Tan, and Y. Zhao, Enrichment of $\beta$ carotene from palm oil using supercritical carbon dioxide pretreatment-solvent extraction 
technique, LWT - Food Sci. Technol., vol. 83, 2017, DOI: 10.1016/j.lwt.2017.05.026.

[13] M. J. H. Akanda, M. Z. I. Sarker, S. Ferdosh, M. Y. A. Manap, N. N. N. A. Rahman, and M. O. A. Kadir, Applications of supercritical fluid extraction (SFE) of palm oil and oil from natural sources, Molecules, vol. 17, no. 2. 2012. DOI: 10.3390/molecules17021764.

[14] R. A. Azmi et al., Deacidification of crude palm oil using PVA-crosslinked PVDF membrane, $J$. Food Eng., vol. 166, 2015, DOI: 10.1016/j.jfoodeng.2015.06.001.

[15] M. R. Ramli et al., Effects of degumming and bleaching on 3-MCPD esters formation during physical refining, JAOCS, J. Am. Oil Chem. Soc., 2011, DOI: 10.1007/s11746-011-1858-0.

[16] T. Nikolaeva et al., Impact of water degumming and enzymatic degumming on gum mesostructure formation in crude soybean oil, Food Chem., vol. 311, May 2020, DOI: 10.1016/j.foodchem.2019.126017.

[17] L. A. Rinćon, J. C. Ramírez, and A. Orjuela, Assessment of degumming and bleaching processes for used cooking oils upgrading into oleochemical feedstocks, J. Environ. Chem. Eng., 2020, DOI: 10.1016/j.jece.2020.104610.

[18] L. L. You, B. S. Baharin, Y. B. C. Man, and S. Takagi, Effect of degumming process on chromatographic separation of carotenes from crude and degummed palm oil, J. Food Lipids, 2001, $\quad$ DOI: $\quad 10.1111 /$ j.17454522.2001.tb00181.x.

[19] C. L. G. Dayton and F. Galhardo, Enzymatic Degumming, in Green Vegetable Oil Processing: Revised First Edition, 2013. DOI: 10.1016/B978-0-9888565-3-0.50009-1.

[20] A. Sein, T. Hitchman, and C. L. G. Dayton, Enzymes in Vegetable Oil Degumming Processes, in Industrial Enzyme Applications, John Wiley \& Sons, Ltd, 2019. DOI: 10.1002/9783527813780.ch4_2.

[21] K. S. Hew et al., Revising degumming and bleaching processes of palm oil refining for the mitigation of 3-monochloropropane-1,2-diol esters (3-MCPDE) and glycidyl esters (GE) contents in refined palm oil, Food Chem., vol. 307, 2020, DOI: 10.1016/j.foodchem.2019.125545.

[22] X. Jiang, M. Chang, Q. Jin, and X. Wang, Application of phospholipase A1 and phospholipase $\mathrm{C}$ in the degumming process of different kinds of crude oils, Process Biochem., 2015, DOI: 10.1016/j.procbio.2014.12.011.

[23] A. W. Nur Sulihatimarsyila, H. L. N. Lau, K. M.
Nabilah, and I. Nur Azreena, Refining process for production of refined palm-pressed fibre oil, Ind. Crops Prod., 2019, DOI: 10.1016/j.indcrop.2018.12.034.

[24] A. J. Dijkstra, About water degumming and the hydration of non-hydratable phosphatides, Eur. J. Lipid Sci. Technol., vol. 119, no. 9, 2017, DOI: 10.1002/ejlt.201600496.

[25] A. W. Nur Sulihatimarsyila, H. L. N. Lau, K. M. Nabilah, and I. Nur Azreena, Production of refined red palm-pressed fibre oil from physical refining pilot plant, Case Stud. Chem. Environ. Eng., vol. 2, Sep. 2020, DOI: 10.1016/j.cscee.2020.100035

[26] S. Paisan, P. Chetpattananondh, and S Chongkhong, Assessment of water degumming and acid degumming of mixed algal oil, $J$. Environ. Chem. Eng., 2017, DOI: 10.1016/j.jece.2017.09.045.

[27] P. N. Mayamol, C. Balachandran, T. Samuel, A. Sundaresan, and C. Arumughan, Process technology for the production of micronutrient rich red palm olein, JAOCS, J. Am. Oil Chem. Soc., vol. 84, 2007, DOI: 10.1007/s11746-0071078-9.

[28] S. V. More, S. Chavan, and A. A. Prabhune, Silk Degumming and Utilization of Silk Sericin by Hydrolysis Using Alkaline Protease from Beauveria Sp (MTCC 5184): A Green Approach, J. Nat. Fibers, vol. 15 , no. 3, May 2018, DOI: 10.1080/15440478.2017.1330718.

[29] S. B. Oey, H. J. van der Fels-Klerx, V. Fogliano, and S. P. J. van Leeuwen, Effective physical refining for the mitigation of processing contaminants in palm oil at pilot scale, Food Res. Int., 2020, DOI: 10.1016/j.foodres.2020.109748.

[30] C. B. Gonçalves, C. E. C. Rodrigues, E. C. Marcon, and A. J. A. Meirelles, Deacidification of palm oil by solvent extraction, Sep. Purif. Technol., vol. 160, 2016, DOI: 10.1016/j.seppur.2016.01.016.

[31] I. W. R. Widarta, A. Nuri, and T. Haryati, Optimasi Proses Deasifikasi dalam Pemurnian Minyak Sawit Merah Skala Pilot Plant, J. Teknol. dan Ind. Pangan, vol. 23, no. 1, 2012.

[32] R. C. Mordi, O. T. Ademosun, C. O. Ajanaku, I. O. Olanrewaju, and J. C. Walton, Free radical mediated oxidative degradation of carotenes and xanthophylls, Molecules. 2020. DOI: 10.3390/molecules25051038.

[33] M. Sarah, S. Widyastuti, and D. Ningsih, Red palm oil production by microwave irradiation, 2018. DOI: 10.1088/1757-899X/309/1/012091. 
[34] A. H. Riyadi, T. R. Muchtadi, N. Andarwulan, and T. Haryati, Pilot Plant Study of Red Palm Oil Deodorization Using Moderate Temperature, Agric. Agric. Sci. Procedia, vol. 9, 2016, DOI: 10.1016/j.aaspro.2016.02.129.

[35] J. Cmolik and J. Pokorny, Physical refining of edible oils.pdf, Eur. J. Lipid Sci. Technol., vol. 102, no. 7, 2000.

[36] Y. Hendrawan, B. Susilo, A. W. Putranto, D. F. Al Riza, D. M. Maharani, and M. N. Amri, RSMCCD Algorithm for Optimizing Waterjet
Vacuum Evaporator Using Fuzzy Temperature Control in The Milk Candy Production, $J$. Agritech, vol. 36, no. 02, 2016, DOI: 10.22146/agritech.12868.

[37] N. Chumuang and V. Punsuvon, Response Surface Methodology for Biodiesel Production Using Calcium Methoxide Catalyst Assisted with Tetrahydrofuran as Cosolvent, J. Chem., 2017, DOI: $10.1155 / 2017 / 4190818$. 